\title{
The Better French Living Project: how to encourage linguistic, practical, and cultural year-abroad preparation outside the classroom
}

\author{
Sandra Salin ${ }^{1}$
}

Abstract

$\mathrm{T}$ his chapter presents the Better French Living Project (BFLP), which was started in 2014 in the French section of the Newcastle University School of Modern Languages (SML) with a view to respond to second-year students' feedback, promote independent learning amongst them, and assist in their year-abroad preparation by developing their practical and intercultural knowledge and listening skills outside the classroom. After introducing the context in which the project was developed, this chapter presents the topics selected, together with samples of the activities that were designed and made available to students via their Virtual Learning Environment (VLE). This is followed by an analysis of the feedback students provided via end-of-year questionnaires in the three academic years from 2014 to 2017, including an assessment of the activities offered and the students' engagement with them. Finally, this chapter suggests how this project could be further developed.

Keywords: year abroad preparation, independent learning, listening skills.

1. Newcastle University, Newcastle upon Tyne, United Kingdom; sandra.salin@newcastle.ac.uk

How to cite this chapter: Salin, S. (2018). The Better French Living Project: how to encourage linguistic, practical, and cultural year-abroad preparation outside the classroom. In F. Rosell-Aguilar, T. Beaven, \& M. Fuertes Gutiérrez (Eds), Innovative language teaching and learning at university: integrating informal learning into formal language education (pp. 79-88). Research-publishing.net. https://doi.org/10.14705/rpnet.2018.22.778 


\section{Introduction}

Three main factors contributed to defining the areas the BFLP should focus on. I derived inspiration from my role as Year Abroad Officer for Francophone countries from direct consultation with final-year students and from my knowledge of the second-year language module. This helped me identify what students found particularly challenging, if not overwhelming, while abroad. As module leader, I was also fully aware of the need to develop year-abroad related material that could address gaps existing in the curriculum, including informal register and practical, everyday life situations.

I gave priority to activities related to France because the vast majority of students going to a francophone country during their year abroad choose France as their destination. I focussed on listening activities because understanding native speakers when they speak spontaneously is usually what my students find most difficult to both understand and practise independently. Exposure to the spoken language also offers more opportunities to practise informal register, respects the way we learn a language naturally, and facilitates the development of other skills (Vandergrift, 1999).

\section{Presentation of the project}

Once the main objectives of the project were defined, existing literature in the fields of emotional and cultural intelligence, cultural shock, and adaptation was reviewed in order to better understand the importance and ways of facilitating the transition into the year abroad (Salin, 2017, pp. 172-178). Shanwal and Kaur (2008), for instance, have shown the extent to which emotions and emotional intelligence can affect learning, thus supporting the idea that developing awareness of challenges and exploring ways of tackling them can smoothen the transition and contribute to deeper learning.

Dealing with practical, everyday life challenges, like securing accommodation or opening a bank account, may appear somewhat trivial in academic settings. 
However, based on my year-abroad students' comments, these practicalities constitute challenges that deeply affect their experience and often make them feel that they are thrown in at the deep end, especially in the first few weeks, all the more so because they feel they have to face them on their own. Thus, addressing these practical aspects - that Winkelman (1994) called fundamentals - before students go abroad aimed to facilitate their transition and adaptation:

"Successful adjustment [...] depends on the availability of transition resources necessary for comfortable adaptation in the new culture. The needs of physical well-being, food and security, must be effectively met if one is to [...] address subsequent needs for social relations, self-esteem, and personal development. Assistance in managing fundamentals such as food, housing, and transportation then frees the individual to focus on the cultural adaptation issues" (p. 124).

The positive link between preparation and experience is well established and has resulted in new approaches to better prepare students for their placements abroad. For instance, collaborative projects such as the ICP2 (1997-2000) and the IEREST $^{3}$ (2012-2015) projects led to the creation of online resources aiming to develop intercultural awareness. Intercultural Communication is also at the heart of the more recent training programme that López-Rocha and Vailes (2017) offer at the University of Bristol .

The BFLP reflects a different approach in the sense that it adopted independent learning material as a means to better prepare students both culturally and linguistically. This choice was determined by two main factors, the first one being the constraints imposed by the second-year language module, which includes students who do not need to prepare for a year abroad in France (either because they already have undertaken their year abroad or because they will not go there during their year abroad). Additionally, I considered promoting independent learning as a way of encouraging students to move away from

2. The Interculture Project: http://www.lancaster.ac.uk/users/interculture/about.htm

3. Intercultural Education Resources for Erasmus Students and their Teachers: http://www.ierest-project.eu/the-project.html 
institutional learning into their year-abroad experience where most of their learning would be experiential.

Based on feedback received from year-abroad and final-year students, the following topics were given priority and formed the basic structure of the project material:

- keeping informed about current affairs;

- cultural differences and stereotypes;

- accommodation;

- formal and informal register;

- daily life and socialising;

- banking;

- secondary and higher education;

- applications and interviews; and

- phone conversations.

Reviewing existing online audio-visual resources revealed a lack of sites that matched the language level required and provided in the same package a mix of registers, year-abroad-related topics, and tasks to complete independently, hence the need to design material addressing our students' specificities.

Most of the activities were designed by an intern, Morgane Mazan, a French Postgraduate student undertaking a Master of Arts in Teaching French as a Foreign Language at the University of Nantes. She was almost the same age as our students and had completed a year abroad herself. The BFLP also matched exactly her experience and the topic she had chosen for her dissertation (Mazan, 2014).

According to Reinders (2010), independent learning is more likely to be successful if students receive clear guidance, instructions, answers, and, even better, prompts to help them reflect on their learning. To that end, Mazan (2014) selected 27 online and homemade audio-visual pieces and prepared guided 
activities, transcriptions, and answer sheets based on them to allow students to work completely independently outside the classroom. She also designed a series of questions and prompts to encourage students to reflect on their own learning and learning styles, what they found difficult, and what steps they could take to improve or overcome these difficulties.

Knowing that even when provided with this kind of support, students still tend to use the material available to them selectively depending on their needs (Reinders, 2010), a pick and mix approach was adopted for the BFLP. Thus, the activities were divided into nine independent units, each corresponding to the above topics, to allow students to focus their independent work on their personal needs and interests.

Although it is not in the remit of this chapter to describe all the material in detail (Mazan, 2014, pp. 89-91, 108-109), it seems relevant to present carefully selected examples to illustrate the pedagogical approach that was applied and the diversity of the areas the students were encouraged to practise.

Some of the audio-visual pieces were selected mainly for their informative nature, but students were still invited to take this opportunity to work on grammar and aspects of spoken French. For example, Mazan used the recorded interview of her French bank manager explaining how to open a bank account to introduce the main banks found in France and key terms related to banking. The transcription was also used to ask students to identify different characteristics of spoken French such as the speech markers voilà, ben, hein, quoi, contractions, and grammatical inaccuracies. This activity was also intended to make them aware of the frequency of unfinished sentences and interruptions in a French conversation (Supplementary materials, part 1).

Other pieces were chosen to develop students' cultural knowledge and awareness more specifically, like those contained in the 'Cultural differences and stereotypes' unit that includes three videos exploring how the French are perceived by American, Belgian, and English people. However, developing emotional intelligence was also on the agenda. For instance, two videos featuring 
Cyprien, a famous French blogger, podcaster and YouTuber, were used to show the main differences between French and English school lives and education systems, but also to prompt students to think about how feelings and emotions are expressed through tones and body language and how these can vary between countries (Cyprien, 2013, 2015).

As mentioned previously, the characteristics of informal, spoken French, as opposed to academic French, was an important aspect of the BFLP, so the unit on formal and informal languages is not the only one offering students the opportunity to work on slang, colloquial expressions, or speed of delivery. Yet, when Norman, another famous YouTuber, Cyprien, and others appear, this is also to cover very practical topics relevant to everyday life like flat sharing, likes and dislikes, reasons for being late, food shopping, or work-related situations.

\section{Student evaluation}

Students were able to access the material from the first semester of 2014-15 via Blackboard. They were left to use it completely independently in order to assess the extent to which this would enable them to take charge of their year-abroad preparation, in the same way as they would be in charge of their own learning during their year abroad.

In the first year of this project, 2014-15, 87 students were enrolled in the course. At the end of Semester 2, students were asked to complete a questionnaire during their last language seminar, including six questions (Supplementary materials, part 2) aiming to assess their use and experience of the project material in particular. Completion was voluntary. In total, 76 students ( $87.3 \%$ of the cohort) completed it and agreed for their answers to be used for research purposes. Thirtytwo respondents $(42.1 \%)$ said that they had used the material. In the following year, 85 students were enrolled, followed by 107 in 2016-17. In an attempt to increase the proportion of students using the material, in 2015-16 I included some of the activities into the language module curriculum as independent homework to complement class content. This explains why the proportion of 
users almost doubled compared to the previous year, as illustrated in Table 1. Looking at actual figures reveals that 50 respondents used the materials in 201516 and 56 in 2016-17.

Table 1. Proportion of respondents who used the BFLP material

\begin{tabular}{|l|l|l|}
\hline $\begin{array}{l}2014-15 \\
\text { (out of } 76 \text { respondents } \\
-87.3 \%\end{array}$ & $\begin{array}{l}2015-16 \\
\text { (out of } 60 \text { respondents } \\
-70.5 \% \text { of the cohort) }\end{array}$ & $\begin{array}{l}\mathbf{2 0 1 6 - 1 7} \\
\text { (out of } 64 \text { respondents } \\
-\mathbf{5 9 . 8 \%} \% \text { of the cohort) }\end{array}$ \\
\hline $42.1 \%$ & $83.3 \%$ & $87.5 \%$ \\
\hline
\end{tabular}

Additional questions were added to the questionnaire to assess how many students had used the material without being prompted in 2015-16 and 2016-17 (Supplementary materials, part 3). The results, 29 (43.3\%) and 28 (43.7\%) students respectively, showed that integrating some of the material into the curriculum did not lead to a significant increase in the number of students using the material without being prompted.

Figure 1 presents the top ten aspects that students liked about the material in 2014-15, 2015-16, and 2016-17, based on the 131 students who named up to three things over the whole period. Preparation for the year abroad, the original motivation behind the project, was what the students liked most often. Students also acknowledged its usefulness in terms of cultural preparation and language practice. As these two aspects and their constant interaction are important characteristics of what constitutes the year-abroad experience, it can be concluded that the BFLP succeeded in making students feel more prepared, if not actually preparing them better.

Out of 140 students who evaluated the BFLP experience in terms of quality and usefulness, 131 found the project good, very good, or excellent between 2014 and 2017. Although integrating some of the material into the language module curriculum allowed me to introduce more year-abroad preparation without taking any additional class time, this also led to a slight drop in the students' positive rating. This would tend to indicate that students are more likely to appreciate the material when they are left to use it independently. Given that not all students on 
the module will go and spend a year abroad in a francophone country because of the structure of our programmes, this also confirms a link existing between the students' satisfaction and how relevant the material is to them.

Figure 1. Aspects students liked the most

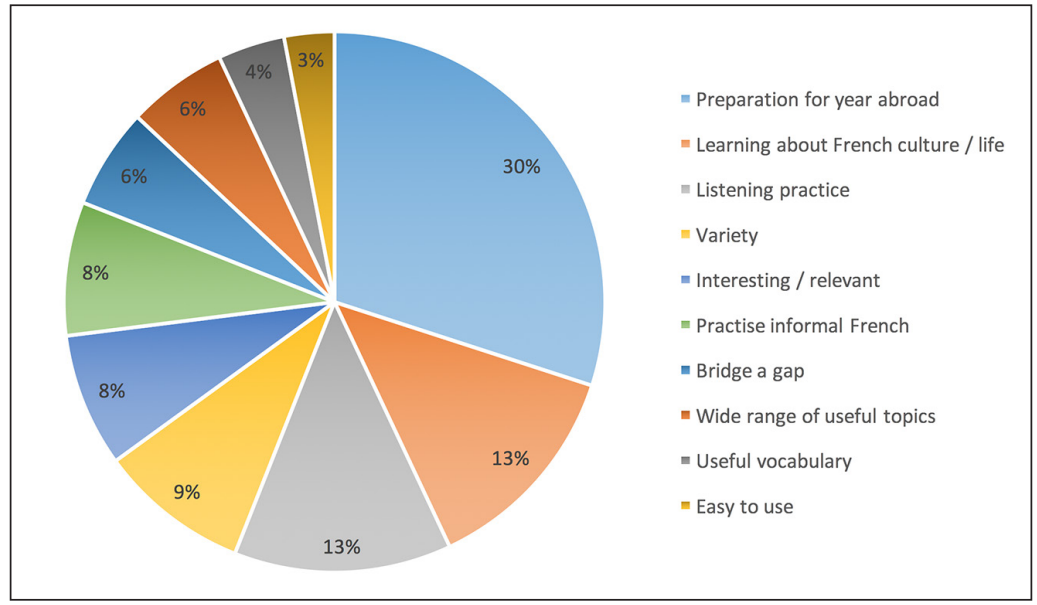

As shown in Table 2, lack of time was the most common reason provided by the students who explained why they did not use the material, even when prompted, over the three years. The other reasons found more than once were personal choice, year abroad destination, and the fact that they had already undertaken their year abroad. The 2014-15 results confirm the need to consider time constraints when developing any extra-curricular activities, while the $2015-17$ percentages seem to indicate that independent learning is considered as competing with other priorities such as deadlines, assessments, and the workload of other modules, as attested by comments left by students.

Table 2. Proportion of respondents who mentioned lack of time as a reason for not engaging with the BFLP material

\begin{tabular}{|l|l|l|}
\hline $\begin{array}{l}2014-15 \\
\text { (out of } 24 \text { respondents) }\end{array}$ & $\begin{array}{l}\mathbf{2 0 1 5}-16 \\
\text { (out of } 27 \text { respondents) }\end{array}$ & $\begin{array}{l}\mathbf{2 0 1 6 - 1 7} \\
\text { (out of } 27 \text { respondents) }\end{array}$ \\
\hline $41.6 \%$ & $33 \%$ & $38.1 \%$ \\
\hline
\end{tabular}




\section{Conclusion}

The BFLP can be regarded as successful since students who engaged with it felt more prepared before embarking on their year abroad. Yet, integrating some of its content in the second-year curriculum did not lead to a significant increase in the number of students adopting it as a regular self-selected learning method, which confirms Reinders's (2010) findings.

Although student feedback gave a clear indication of the usefulness of the project before going abroad, further investigation amongst returning students would be needed to evaluate the extent and the kind of impact it had on their year-abroad experience. This could potentially lead to a better understanding of the significance of emotions and feelings, such as enjoyment or confidence, in their learning journey.

A recent survey amongst final-year students has revealed a growing interest in other francophone countries or regions, such as Belgium, Switzerland, and Quebec. The BFLP could be the perfect platform to respond to this kind of demand by offering activities related to these areas. As the project material is now available to all Newcastle University students via the University Internet Protocol TV system, such a development could benefit all students - not just SML students - wishing to go and study or work in a francophone country as part of their degrees. This would go well with the fact that all Newcastle University students are now allowed to undertake a placement year in the UK or abroad as part of their studies.

\section{Supplementary materials}

https://research-publishing.box.com/s/lwqciretknlcd5n2vstaeqioljr0wjed

\section{References}

Cyprien. (2013). L'école. YouTube. http://www.youtube.com/watch?v=RL7grUEo960 
Cyprien. (2015). Mentions Bac. Dailymotion. http://www.bing.com/videos/search?q=Cyprie $\mathrm{n}+$ mentions + Bac\&view=detail \& mid=439FE41655298423D0B4439FE41655298423D0 B4\&FORM=VIRE

López-Rocha, S., \& Vailes, F. (2017). Developing intercultural communicative competence for the year abroad experience. In C. Álvarez-Mayo, A. Gallagher-Brett \& F. Michel (Eds), Innovative language teaching and learning at university: enhancing employability ( $\mathrm{pp}$. 67-75). Research-publishing.net. https://doi.org/10.14705/rpnet.2017.innoconf2016.656

Mazan, M. (2014). Comment sensibiliser des étudiants de l'université de Newcastle à la compétence de compréhension orale du français parlé : mise en place d'un dispositif d'auto apprentissage semi-guidé. Unpublished MA Dissertation. Université de Nantes.

Reinders, H. (2010). Towards a classroom pedagogy for learner autonomy: a framework of independent language learning skills. Australian Journal of Teachers Education, 35(5), 40-55. https://doi.org/10.14221/ajte.2010v35n5.4

Salin, S. (2017). The Better French Living Project: preparing students for 'difference' in France. In R. Whittle \& S. Salin (Eds), Preparing modern languages students for 'difference'(pp. 169-198). Peter Lang.

Shanwal, V. K., \& Kaur, G. (2008). Emotional intelligence in education: applications and implications. In: R. J. Emmerling, V. K. Shanwal, \& M. K. Mandal (Eds), Emotional intelligence: theoretical and cultural perspectives (pp. 153-170). Nova.

Vandergrift, L. (1999). Facilitating second language listening comprehension: acquiring successful strategies. ELT Journal, 53(3), 168-176. https://doi.org/10.1093/elt/53.3.168

Winkelman, M. (1994). Cultural shock and adaptation. Journal of Counselling and Development, 73(2), 121-126. https://doi.org/10.1002/j.1556-6676.1994.tb01723.x 


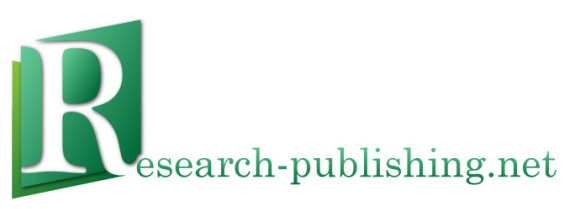

Published by Research-publishing.net, a not-for-profit association

Voillans, France, info@research-publishing.net

(C) 2018 by Editors (collective work)

(C) 2018 by Authors (individual work)

Innovative language teaching and learning at university:

integrating informal learning into formal language education

\section{Edited by Fernando Rosell-Aguilar, Tita Beaven, and Mara Fuertes Gutiérrez}

Rights: This volume is published under the Attribution-NonCommercial-NoDerivatives International (CC BYNC-ND) licence; individual articles may have a different licence. Under the CC BY-NC-ND licence, the volume is freely available online (https://doi.org/10.14705/rpnet.2018.22.9782490057108) for anybody to read, download, copy, and redistribute provided that the author(s), editorial team, and publisher are properly cited. Commercial use and derivative works are, however, not permitted.

Disclaimer: Research-publishing.net does not take any responsibility for the content of the pages written by the authors of this book. The authors have recognised that the work described was not published before, or that it was not under consideration for publication elsewhere. While the information in this book is believed to be true and accurate on the date of its going to press, neither the editorial team nor the publisher can accept any legal responsibility for any errors or omissions. The publisher makes no warranty, expressed or implied, with respect to the material contained herein. While Research-publishing.net is committed to publishing works of integrity, the words are the authors' alone.

Trademark notice: product or corporate names may be trademarks or registered trademarks, and are used only for identification and explanation without intent to infringe.

Copyrighted material: every effort has been made by the editorial team to trace copyright holders and to obtain their permission for the use of copyrighted material in this book. In the event of errors or omissions, please notify the publisher of any corrections that will need to be incorporated in future editions of this book.

Typeset by Research-publishing.net

Cover design by (C Raphäl Savina (raphael@savina.net)

ISBN13: 978-2-490057-10-8 (Ebook, PDF, colour)

ISBN13: 978-2-490057-11-5 (Ebook, EPUB, colour)

ISBN13: 978-2-490057-09-2 (Paperback - Print on demand, black and white)

Print on demand technology is a high-quality, innovative and ecological printing method; with which the book is never 'out of stock' or 'out of print'.

British Library Cataloguing-in-Publication Data.

A cataloguing record for this book is available from the British Library.

Legal deposit, UK: British Library.

Legal deposit, France: Bibliothèque Nationale de France - Dépôt légal: juin 2018. 